\title{
Trend Iklan Politik Luar Ruang Dalam Ruang Media Massa
}

\section{(The Trend of Outdoor Political Advertising in Mass Media Space)}

\author{
Khairatun Hisan ${ }^{1 \times}$, Anang Anas Azhar ${ }^{2}$ \\ ${ }^{1}$ Program Studi Komunikasi dan Penyiaran Islam, Universitas Islam Negeri Sumatera Utara Medan, Indonesia \\ 2 Program Studi Komunikasi dan Penyiaran Islam, Universitas Islam Negeri Sumatera Utara Medan, Indonesia \\ 凶email: adzkiakoe@gmail.com
}

\begin{tabular}{ccc}
\hline First received: & Revised: & Final Accepted: \\
17 October 2020 & 16 November 2020 & 30 December 2020 \\
\hline
\end{tabular}

\begin{abstract}
Outdoor political advertising is a medium that is often used by prospective candidates who will contest the Pilkada. As an information medium, it is believed to be a powerful way to introduce oneself to the voting community of potential leaders and their vision and mission. The method used is qualitative-descriptive by observing advertisements in the form of banners containing photos and political jargon of prospective leaders in the 2020 Medan regional elections. The result of the research is that advertising banners display main information in the form of photos of prospective candidates and taglines according to the vision offered. The target audience for prospective advertising banners is the general public.
\end{abstract}

Keywords : Advertising; Outdoor; And Mass Media.

\section{ABSTRAK}

Iklan politik luar ruang merupakan media yang sering digunakan para bakal calon yang akan bertarung di Pilkada. Sebagai media informasi dalam ajang pilkada diyakini sebagai cara ampuh untuk memperkenalkan diri kepada masyarakat pemilih calon pemimpin dan visi misinya. Metode yang digunakan adalah kualitatif-deskriptif dengan mengamati iklan-iklan dalam bentuk spanduk yang berisi photo dan jargon politik calon pemimpin dalam pilkada kota Medan 2020. Hasil penelitian adalah spanduk iklan menampilkan informasi utama berupa photo bakal calon dan tagline sesuai dengan visi yang ditawarkan. Sasaran audiens spanduk iklan bakal calon adalah masyarakat umum.

Kata kunci : Iklan; Luar Ruang; Media Massa.

\section{PENDAHULUAN}

Menjelang pemilihan kepala daerah, seperti juga iklan, banyak beredar spanduk-spanduk yang berisi informasi mengenai calon pemimpin tersebut. Umumnya spanduk itu menampilkan fotobakal calon dan namanya dengan dibumbui kalimat singkat tentang visi calon jika menjadi kepala daerah atau tagline (jargon). Dari tahun ke tahun, kegiatan Pilkada selalu diwarnai dengan 'perang' spanduk pasangan calon yang akan bertarung. Apa yang ditampilkan dalam spanduk, umumnya bersifat retoris atau janji-janji pasangan calon yang digunakan untuk meraih dukungan pada saatnya pemilihan berlangsung nanti (Darmawan, 2018)

Sebagai bentuk komunikasi politik, iklan politik dirayakan dan dicaci maki. Selama lima dekade terakhir, sejak kemunculan pertamanya dalam kampanye pada tahun 1950-an, iklan politik telah berkembang menjadi bentuk komunikasi yang dominan antara kandidat dan pemilih di Amerika Serikat. Dalam berbagai bentuk dan gaya, iklan politik juga telah menjadi bahan komunikasi pokok dalam demokrasi di seluruh dunia. Oleh karena itu, tidaklah mengherankan bahwa penelitian tentang iklan politik telah menjadi salah satu komponen terpenting dari disiplin komunikasi politik (Kaid, 2004: 155). Sejarah iklan politik diawali di AS sejalan dengan keberhasilan para kapitalis pada abad ke-20 dalam hal teknik-teknik pencarian dana dengan menjadikan politik sebagai sumber keuangan. Penggunaan media untuk menjual para politisi bukan fenomena baru. Jauh sebelum era media elektronik, media-media seperti pamflet, poster, 
surat kabar dan pertunjukan-pertunjukan publik misalnya parade dan pawai digunakan sebagai iklan politik. Isinya yakni mengajak orang untuk memilih calonnya dan menolak calon yang lain. Bahkan sejak Jefferson, Jackson, Lincoln penggunaan iklan untuk kegiatan politik sudah dilakukan dengan berbagai cara, misalnya melalui transparasi, spanduk, kartun dan lagu-lagu (Cangara, 2018: 303).

Iklan politik adalah "proses komunikasi di mana suatu sumber (biasanya kandidat atau partai politik) membeli kesempatan untuk mengekspos penerima melalui saluran massa ke pesan politik dengan efek yang dimaksudkan untuk mempengaruhi sikap, keyakinan, dan / atau perilaku politik mereka"(Kaid, 2004: 155).

Iklan Politik adalah salah satu bentuk pemasaran, bentuk iklan yang dibentuk untuk mempersuasi orang, sehingga menciptakan kebutuhan audiencenya, membujuk pihak lain agar sepakat dengan pendapat pihak yang membujuk. Iklan politik adalah alat jualan untuk menimbulkan kebutuhan akan konstituen terhadap parpol atau tokoh yang beriklan, sehingga mendapatkan dukungan. Persoalannya apa dari iklan-iklan yang ada saat ini konstiuen akan terpengaruh. Ada 3 efek dalam merauk konstituen dalam beriklan, yaitu: mengenal, kemudian mendukung lalu terakhir adalah memilih (Boer, 2014: 298).

Menurut Jamieson ada tiga macam iklan/kampanye politik: Pertama, Iklan advokasi kandidat: memuji-muji (kualifikasi) seorang calon, pendekatannya bisa, retrospective policysatisfaction (pujian atas prestasi masa lalu kandidat), atau benevolent-leader appeals (kandidat memang bermaksud baik, bisa dipercaya, dan mengidentifikasi diri selalu bersama/menjadi bagian pemilih) iklan advokasi isu, dipasang oleh pihak independen untuk menyampaikan isu-isu penting (lingkungan hidup, pengangguran dll) yang diarahkan pada satu atau beberapa iklan atau ungkapan-ungkapan kampanye dari satu atau beberapa kandidat; Kedua, Iklan menyerang (attacking), berfokus pada kegagalan dan masa lalu yang jelek dari kompetitor, pendekatannya bisa ritualistic (mengikuti alur permainan lawannya, ketika diserang, akan balik menyerang); Ketiga, Iklan memperbandingkan (contrasting): menyerang tapi dengan memperbandingkan data tentang kualitas, rekam jejak, dan proposal antar-Kandidat (Boer, 2014: 298).

Perkembangan demokrasi di Indonesia semakin membuka peluang praktisi politik untuk melakukan kampanye secara terbuka. Media massa sebagai bagian dari saluran komunikasi politik, menjaditarget penting untuk melakukan sosialisasi politik. Aktivitas politik pada dasarnya merupakan aktivitas yang tidak bisa dipisahkan dari berbagai bentuk aktivitas manusia. Baik secara langsung (Tabroni, 2012). Iklan Politik Media Luar Ruang, menampilkan kandidat dengan gambar nyata yaitu : photo kandidat dengan gesture tertentu , logo partai politik, nama partai politik, tag line, nomor urut, background warna partai, dan nama caleg (Suryono et al., 2019).

Setiap kegiatan pemilihan umum, iklan politik memiliki peran yang sangat penting. Iklan politik mampu memberitahukan kepada masyarakat tentang kehadiran calon pemimpin yang layak untuk dipilih atau tidak dipilih. Iklan politik muncul di media-media politik yang sangat pesatnya perkembangannya saat kampanye-kampanye politik. Sejak kemunculan pertama dalam kampanye pada 1950-an, iklan politik telah berevolusi menjadi bentuk komunikasi dominan antara kandidat dan pemilih (Kaid, 2004). Iklan politik memiliki pengaruh yang besar, untuk membujuk para pemilih melalui perspektif partai politik maupun kandidat (O'Shaughnessy, 2001). Iklan politik sebagai jendela yang dapat menghubungkan partai politik dengan para pemilih. Partai politik, calon legislatif, calon presiden dan wakil presiden menggunakan iklan politik dalam memenangkan pemilihan umum (Tinarbuko, 2011).

\section{METODE PENELITIAN}

Penelitian ini menggunakan jenis penelitian kualitatif dengan pendekatan deskriptif. Penelitian dilakukan dengan mengamati iklan-iklan politik calon pemimpin pada pilkada kota Medan 2020. Spanduk iklan bakal calon walikota memiliki kode-kode visual berupa tulisan gambar dan warna. 
Objek penelitian berupa spanduk iklan pilkada yang terpasang di beberapa jalan prototol selama proses promosi para calon untuk memperkenalkan diri pada masyarakat pemilih.

\section{HASIL PENELITIAN DAN PEMBAHASAN}

Menjelang pilkada kota Medan 2020, banyak politikus yang memanfaatkan iklan sebagai sarana penyampaian pesan kepada khalayak. Para calon membuat spanduk yang dipasang dibeberpaa ruas jalan, dan pada umumnya tampilan spanduk iklan pilkada menampilkan photo wajah calon dan disertai tagline (jargon) atau visi dan misi secara singkat. Iklan ini bisa berupa papan reklame, baliho, banner, spanduk atau poster dengan tujuan agar masyarakat mengenali calon pemimpin yang akan datang.

Iklan politik outdoor menjadi trend promosi dalam ajang pilkada. Sebagaimana iklan indoor yaitu televisi, surat kabar, radio memberikan pengaruh kepada pembaca atau pemirsa, maka begitu juga pada iklan politik outdoor dalam ruang media massa yang menampilkan sosok figur dengan menyampaikan pesan-pesan yang paling baik, dengan menampilkan isu-isu global yang dibincangkan pada daerah masing-masing sebagai pesan tersirat dari janji-janji politik para calon.

Peran iklan politik outdoor dalam ruang media massa dalam faktanya menghabiskan tidak sedikit biaya iklan, bahkan bisa menjangkau ratusan milyar apalagi jika para bakal calon pemimpin banyak menggunakan media baliho, kemudian papan billboard, sehingga pemasukan atau income yang sangat besar didapatkan oleh para pengusahan papan billboard menjelang acara pilkada.

Sebuah poster atau spanduk ditujukan untuk memberikan informasi kepada audiens melalui elemenelemen visual yang terkandung di dalamnya. Informasi yang disampaikan dalam media luar ruang tersebut merupakan hasil pilihan dari beberapa kemungkinan yang ditentukan oleh kreatornya. Audiens akan membaca informasi dalam poster atau spanduk melalui proses encoding dan akan memilih makna tertentu dari sekian banyak kemungkinan yang muncul dari tanda-tanda yang digunakan dalam media publikasi tersebut. Spanduk iklan politik merupakan media yang sering digunakan para bakal calon yang akan bertarung di Pilkada. Sebagai media informasi. Sebuah iklan akan melakukan fungsinya sebagai media promosi sehingga perlu menampilkan sesuatu yang menjadi stopping power bagi audiens, berupa hal yang mampu memunculkan daya tarik dan motivasi dalam diri audiens agar memiliki keinginan seperti yang ditampilkan dalam iklan dengan menggunakan produk yang diiklankan. Meskipun realitasnya akan berbeda pada masing-masing audiens (Darmawan, 2018).

\section{Iklan Politik Dalam Ruang}

Salah satu aspek penting dalam aktivitas komunikasi politik adalah media massa. Sebagai produk dari aktivitas jurnalistik, media massa memiliki kelebihan yang tidak mungkin dilakukan oleh orang perorang. Keluasan jangkauan dan kedalaman pengaruh media massa selalu menjadi buruan para komunikator politik. Bagaimana sebuah pesan politik bisa sampai kepada publik, sangat tergantung kepada sejauh mana para komuni kator politik bisa menyertakan media massa dalam setiap aktivitas komunikasi politiknya (Tabroni, 2012).

Dalam konteks inilah media massa menjadi sangat penting untuk kepentingan komunikasi politik. Setidaknya, media massa memiliki lima fungsi yang dapat dimanfaatkan komunikator politik untuk mewujudkan tujuannya: Pertama, Fungsi informasi. Media massa selalu menjadi sumber informasi dalam berbagai tayangan atau peristiwa politik yang terjadi diberbagai belahan planet bumi termasuk aktivitas aktor-aktor politik dengan sikap dan perilaku politik yang melekat pada para aktor tersebut. Sebagai fungsi informasi media massa lebih menitik beratkan kepada unsur-unsur berita yang berefek politik. Kedua, Fungsi Partisipasi. Hal ini menunjukkan bahwa setiap unsur berita harus mampu membangkitkan keikutsertaan masyarakat didalam turut mendukung segala kebijaksanaan pemerintah selama kebijaksanaan tersebut berkait dengan 
kepentingan masyarakat. Ketiga, Fungsi ketiga, sosialisasi dan pendidikan politik. Fungsi ini untuk meningkatkan kualitas rujukan masyarakat didalam menerima dan mempertahankan sistem nilai atau sistem politik yang sedang berlangsung. Kedua bentuk kegiatan ini merupakan proses belajar yang berlangsung dal am waktu lama. Keempat, Fungsi mengembangkan budaya politik yang disebut juga fungsi politisasi. Fungsi ini merupakan fungsi penentu terhadap fungsifungsi lainnya, karena fungsi budaya politik yaitu fungsi untuk membentuk pola perilaku yang memberi warna dominan terhadap karakter suatu bangsa. Kelima, Fungsi Integritas Bangsa. Fungsi ini merupakan syarat mutlak bagi kehidupan negara di dalam mencapai tujuannya (Tabroni, 2012).

Penggunaan media sangatlah penting dalam proses kampanye dan sosialisasi politik modern. Media massa bukan hanya bagian integral dari politik, tetapi juga memiliki posisi yang sentral dalam politik, mampu menyusun realitas dari berbagai peristiwa yang terjadi hingga menjadi wacana yang memiliki kekuatan mengkampanyekan politik. Guna memenangkan kompetisi diajang pemilu, kontestan parpol bersaing dengan menerapkan strategi komunikasi politik yang jitu. Kajian pesan atau teks media massa merupakan bagian dari kajian media massa. Bagaimana proses media massa terjadi, bagaimana media massa membentuk perilaku masyarakat, bagaimana media massa mendorong kemajuan masyarakat dengan sajian pesan (isi) yang terdistribusi dengan cepat dan serentak, sampai dengan bagaimana media massa menjadi penyebab yang mengakibatkan terjadinya kemerosotan moral pada masyarakat. Semua itu menjadi perhatian utama dalam riset media (Boer, 2014: 297).

\section{Iklan Politik Luar Ruang}

Hiruk pikuk iklan politik pada era reformasi tidak hanya menerpa media massa (media elektronik, media cetak, dan media sosial), tetapi juga dalam media luar ruang (outdoor). Pada era ini, media luar ruang menjadi salah satu tren unggulan untuk menginformasikan, memperkenalkan, serta mempromosikan layanan jasa dan produk-produk baru. Media luar ruang pun mulai digunakan partai politik dan para kandidatnya, baik kandidat DPR RI, DPD, DPRD, maupun calon presiden-wakil presiden dan kepala daerah-wakil kepala daerah. Penggunaan media luar ruang sebagai salah satu metode menawarkan diri, baik secara komunal dalam satu partai maupun individual bagi para kandidat, memang bukan barang baru. Puluhan tahun kebelakang, media luar ruang sudah menjadi salah satu metode untuk menawarkan barang atau jasa, termasuk menawarkan pilihan politik. Namun, khusus dalam dunia politik, media luar ruang menjadi salah satu metode komunikasi politik yang diidolai. Dalam mensosialisasikan program kampanye para pemimpin negara biasanya akan memengaruhi masyarakat agar memilih pasangan calon mereka yang dilakukan oleh tim sukses dan berusaha mengemas pesan sebaik mungkin dan semenarik mungkin untuk disampaikan kepada public baik melalui spanduk, baliho, poster, stiker, dan atribut kampanye lainnya (Hikmat, 2019: 263).

\section{Pengaruh Iklan Politik dan Popularitas Figur}

Temuan bahwa keterpaparan pada spot politik dapat mempengaruhi evaluasi citra kandidat telah dikonfirmasi dalam pengaturan penelitian eksperimental dan survei. Banyak studi yang telah mengukur efek iklan negatif pada penarikan kembali dan citra kandidat juga telah mengidentifikasi efek pada perilaku pemungutan suara, yang mengarah ke kesimpulan yang jelas bahwa iklan negatif memang mempengaruhi preferensi pemungutan suara. Kampanye negatif efektif untuk penantang. Alih-alih menggunakan iklan negatif yang asli, mereka memberi kode pada artikel surat kabar untuk mewakili nada (negatif atau positif) kampanye, bahwa kampanye negatif tampaknya berhasil untuk penantang, sedangkan kampanye positif tampaknya lebih efektif untuk kandidat politik petahana. Konteks di mana iklan negatif ditampilkan juga dapat mempengaruhi kemungkinan suara. Untuk Misalnya, iklan negatif sangat mungkin mempengaruhi keputusan suara ketika ditampilkan dalam lingkungan berita (Kaid, 2004). 


\section{PENUTUP}

Media massa mempunyai peran penting dalam kepentingan komunikasi politik, baik dalam dalam ruang maupun diluar ruang yang dapat dimanfaatkan komunikator politik untuk mewujudkan tujuannya. Karena menjadi sumber informasi dan sosialisasi kepada masyarakat untuk memperkenalkan figur atau sosok pemimpin yang akan tampil dengan menjual isu global yang terjadi dimasyarakat yang menjadi janji politik, dengan makna tersirat agar masyarakat memilihnya. Trend iklan politik outdoor dalam ruang media massa membukan peluang praktisi politik untuk melakukan kampanye secara terbuka secara efektif.

\section{DAFTAR PUSTAKA}

Boer, K. M. (2014). Iklan Partai Politik dan Politik Media. Jurnal Visi Komunikasi, 13(2). http://dx.doi.org/10.22441/jvk.v13i2.1660.

Cangara, H. (2018). Komunikasi Politik: Konsep, Teori, dan Strategi Edisi Revisi 2016 (cet. 6). Jakarta: RajaGrafindo Persada.

Darmawan, F. (2018). Modalitas Visual Komunikasi Politik Iklan Pilkada Kota Bandung 2018. Mediator: Jurnal Komunikasi, 11(1), 56-65. https://doi.org/10.29313/mediator.v11i1.3155.

Hikmat, M. M. (2019). Komunikasi Politik Dalam Pilkada Langsung Teori dan Praktik Edisi Revisi. Bandung: Simbiosa Rekatama Media.

Kaid, L. L. (Ed.). (2004). Handbook of Political Communication Research. Lawrence Erlbaum Associates.

O'Shaughnessy, N. (2001). The Marketing of Political Marketing. European Journal of Marketing, 35(9/10), 1047-1057. https://doi.org/10.1108/03090560110401956

Suryono, J., Astuti, P. I., Rahayu, N. T., Hariyanto, H., \& Widayati, M. (2019). Karikatur Iklan Politik Media Luar Ruang Jangan Membeli Kucing Dalam Karung. Profetik: Jurnal Komunikasi, 12(1), 46. https://doi.org/10.14421/pjk.v12i1.1539.

Tabroni, R. (2012). Etika Komunikasi Politik dalam Ruang Media Massa. Jurnal Ilmu Komunikasi, 10(2), 105-116. https:// doi.org/10.31315/jik.v10i2.122

Tinarbuko, S. (2011). Menakar Iklan Politik Pemilu 2009. Nirmana, 11(2). https://doi.org/10.9744/nirmana.11.2.pp.\%20114-124. 